\title{
Suffering as Separation: Towards a Spatial Reading of Psalm 11
}

\author{
Gert T. M. Prinsloo (University of Pretoria)
}

\begin{abstract}
Every human being inevitably experiences illness, loss, failure, and disappointment. When it happens to a perceived-to-be "righteous" person, the problem of theodicy arises, the question whether it is just when deities allow righteous human beings to suffer. The existential crisis caused by severe suffering is a central theme in the Psalter. This study departs from the working hypothesis that suffering can be described in spatial terms and illustrates it with reference to $P s$ 11. Ultimately suffering implies separation from $Y H W H$ and his saving presence at-centre (Ps 11:2-3). In the universe as imagined by the poet there is but one solution: to take refuge in YHWH (11:1) at-centre. That confession, amidst the crumbling of personal security and comfort (11:2-3), draws the eyes of the poet to YHWH in his holy temple and in heaven. In 11:4 the poet's imagined space transports him from שמים to. There, in the presence of YHWH (11:7), he arrives at-centre, convinced that the wicked will finally be destroyed.
\end{abstract}

\section{A INTRODUCTION}

Suffering can be described as "the universal experience of the human race." Every human being at some stage, inevitably, experiences illness, loss, failure, and disappointment. When it happens to a perceived-to-be "righteous" person, the problem of theodicy arises, the question whether it is just when deities allow righteous human beings to suffer. ${ }^{2}$ For Walter Brueggemann it is "the ultimate, inescapable problem of the Old Testament" because the HB insists that

* Article submitted: 7 October 2015; accepted: 9 November 2015. To cite: Gert T. M. Prinsloo, "Suffering as Separation: Towards a Spatial Reading of Psalm 11," Old Testament Essays (New Series) 28 no. 3 (2015): 777-806. DOI: http://

dx.doi.org /10.17159/2312-3621/2015/v28n3a13

1 John T. Willis, "The Dignity and Suffering of Humankind According to the Hebrew Bible," SCJ 1 (1998): 231-41.

2 The term "theodicy" was first used by the German philosopher Gottfried Wilhelm Leibniz in his book Essais de Théodicée sur la bonté de Dieu, la liberté de l'homme et l'origine du mal published in 1710, cf. Gottfried W. Leibniz, Theodicy: Essays on the Goodness of God, the Freedom of Man and the Origin of Evil (trans. E. M. Huggard; New York: Cosimo, 2009). The question, however, has been wrestled with by human beings through all ages, cf. Hans Kessler, Gott und das Leid seiner Schöpfung: Nachdenkliches zur Theodizeefrage (Würzburg: Echter Verlag, 2000). 
"God's world is morally coherent and assured by God's rule."3 The assertion "does not square very well with lived reality." Hence the theme of the suffering of the righteous is prevalent in the Bible, ${ }^{5}$ and as far as the $\mathrm{HB}$ is concerned, ${ }^{6}$ prominent in the prophetic literature, ${ }^{7}$ in $\mathrm{Job}^{8}{ }^{8}$ the Psalms, ${ }^{9}$ and Lamentations. ${ }^{10}$ Human beings' reaction to suffering is as universal as the experience of suffering. It "brings disjunction and discordance, and in the existential crisis which follows severe suffering, human beings - both individually and in community - struggle to construct meaning."11 The existential crisis associated with suffering is a central theme in the Psalter. ${ }^{12}$

In this study I argue that spatial concepts lie at the heart of suffering human beings' struggle to construct meaning. Taking cognisance of a text's spatial dimensions can aid us in understanding the psalmists' struggle to construct meaning in the disjunction and discordance brought about by suffering. I investigate this premise via a spatial reading of Ps 11. I argue that the poem is structured in such a way that the centrally located v. 4 invites us to

3 Walter Brueggemann, "Some Aspects of Theodicy in Old Testament Faith," PRSt 26 (1999): 253-68 (253). Cf. also Walter Brueggemann, "Theodicy in A Social Dimension," JSOT 33 (1983): 3-25.

4 Brueggemann, "Aspects of Theodicy," 256-7.

5 Erhard S. Gerstenberger and Wolfgang Schrage, eds., Leiden (BibKon 1004; Köln: Kohlhammer, 1977); Antii Laatto and Johannes C. de Moor, eds., Theodicy in the World of the Bible (Leiden: Brill, 2003); Keith Warrington, "Healing and Suffering in the Bible," IRM 93 (2006): 154-64.

6 James L. Crenshaw, ed., Theodicy in the Old Testament (IRT 4; Philadelphia: Fortress Press, 1983).

7 David P. Melvin, "Why Does the Way of the Wicked Prosper? Human and Divine Suffering in Jeremiah 11:18-12:13 and the Problem of Evil," EvQ 83 (2011): 99-106; James D. Nogalski, "Recurring Themes in the Book of the Twelve: Creating Points of Contact for a Theological Reading," Int 61 (2007): 125-36.

8 Kenneth Ngwa, "Did Job Suffer for Nothing? The Ethics of Piety, Presumption and the Reception of Disaster in the Prologue of Job," JSOT 33 (2009): 359-80; Larry J. Waters, "Elihu's Categories of Suffering from Job 32-37," BSac 166 (2009): 40520; Tony Campbell, “God and Suffering - 'It Happens': Job's Silent Solution,” ATI 3 (2010): 153-63.

9 Ralph K. Moore, An Investigation of the Motif of Suffering in the Psalms of Lamentation (Ann Arbor, Mich.: UMI, 1993); Fredrik Lindström, Suffering and Sin (trans. M. McLamb; Stockholm: Almqvist \& Wiksell, 1994).

10 Elizabeth Boase, "Constructing Meaning in the Face of Suffering: Theodicy in Lamentations," VT 58 (2008): 449-68.

11 Boase, "Constructing Meaning," 449.

12 Claus Westermann, Praise and Lament in the Psalms (trans. R. N. Soulen and K. R. Crim; Atlanta: John Knox, 1981), 30-35; Craig C. Broyles, The Conflict of Faith and Experience in the Psalms: A Form-Critical and Theological Study (Sheffield: JSOT Press, 1989). 
read "from centre." I will briefly argue that this reading from centre has implications for the interpretation of Pss 3-14 as a psalm group as well. ${ }^{13}$

\section{B SUFFERING: SPATIAL PERSPECTIVES}

The geographer Yi-Fu Tuan emphasised that human beings' sense of place and space is intricately linked to personal experience. ${ }^{14}$ My presupposition is that the spatial references in the Psalter have been filtered through the experience(s) of their authors/redactors and reflect the real-life experiences of these group(s). Adherents of critical spatiality remind us that space is a three-dimensional concept. ${ }^{15}$ The French Marxist philosopher Henri Lefebvre argued that ultimately space should be regarded as a social phenomenon. ${ }^{16}$ It is produced in the interaction between human beings and their environment. ${ }^{17}$ Space is at the same time a physical, mental and social construct. ${ }^{18}$ The American geographer Edward W. Soja uses the terms Firstspace, Secondspace and Thirdspace to describe this trialectic of spaces. ${ }^{19} \mathrm{He}$ emphasizes that Thirdspace (or lived

13 Frank-Lothar Hossfeld and Erich Zenger, Psalm 1-50 (vol. 1 of Die Psalmen; NEchtB 29; Würzburg: Echter Verlag, 1993), 13 regards Pss 3-14 as the first "Teilsammlung" in Book I (Pss 3-41) of the Psalter. Book I is called the "First Davidic Collection" because only Pss 8 and 33 do not have the designation לדוד in their superscripts. Hossfeld and Zenger indicate that the first psalm group (Pss 3-41) is concerned with "die leidvolle Existenz der Armen und Gerechten inmitten einer bosen Welt."

14 Yi-Fu Tuan, Space and Place: The Perspective of Experience (Minneapolis: University of Minnesota Press, 2008), 8-18. Tuan states: "In experience, the meaning of space often merges with that of place. 'Space' is more abstract than 'place.' What begins as undifferentiated space becomes place as we get to know it better and endow it with value." Tuan, Space and Place, 6.

15 Jon L. Berquist, "Critical Spatiality and the Construction of the Ancient World," in 'Imagining' Biblical Worlds: Studies in Spatial, Social and Historical Constructs in Honor of James W. Flanagan (ed. David M. Gunn and Paula M. McNutt; JSOTSup 359; Sheffield: Sheffield Academic Press, 2002), 14-29; Gert T. M. Prinsloo, "The Role of Space in the שירי המעלות (Psalms 120-134)," Bib 86 (2005): 457-77.

16 Henri Lefebvre, The Production of Space (trans. D. Nicholson-Smith; Oxford: Blackwell, 1991), 1.

17 Berquist, "Critical Spatiality," 14-15 remarks in this regard: "Space is something we make, create, produce, shape, reshape, form, inform, disform, and transform."

18 Lefebvre, Production of Space, 11; 38-39 refers to physical space, i.e. "perceived space" (nature, cosmos, place); mental space, i.e. "conceived space" (representations of space, conceptualized space); social space, i.e. "lived space" (spaces of representation, space as experienced).

19 Edward W. Soja, Thirdspace: Journeys to Los Angeles and Other Real-and-Imagined Places (Oxford: Blackwell, 1996), 66-67. Firstspace is physical/concrete/perceived space. Secondspace is imagined/conceived/abstract space. Thirdspace is lived space, the confrontation between social groups and their space(s), reflecting the spatial ideology of society. Cf. Berquist, "Critical Spatiality," 20. 
space) is "the terrain for the generation of 'counterspaces,' spaces of resistance to the dominant order . . . to lived space as a strategic location from which to encompass, understand, and potentially transform all spaces simultaneously." 20

According to Leonard L. Thompson mankind in the HB is presented from two perspectives: "man at-center properly orientated to his world, or man off-center in chaos and disorientation." ${ }^{21}$ In the book of Psalms one encounters an "I" - a 1st person narrator - using language that "embodies the beliefs of the society in which it arose",22 and describes "typical situations" easily recognisable as "existential situations" that are "experienced by many different people." 23 In depicting this "I" and his world, "two types of situations recur: either the ' $\mathrm{I}$ ' is at the center, the desideratum of human existence; or he is offcenter, in a state of distress and disequilibrium.",24

In the spatial imagination of the authors/redactors of the $\mathrm{HB}$ the Jerusalem temple is the centre of their universe. ${ }^{25}$ It is "the 'place' where the 'I' in distress desires to be." 26 At-centre/off-centre can be experienced on two planes. ${ }^{27}$ Horizontally, the binary pair "far/near" expresses this experience. To be "far" from the temple implies to be off-centre, in distress, far from YHWH and his saving presence. Vertically, the binary pair "ascend/descend" expresses the same concept. To "descend" implies to be off-centre, to leave the saving presence of YHWH, to disappear into the depths of Še'ôl. ${ }^{28}$ Approaching (horizontally) and ascending (vertically) to Jerusalem/Zion at the centre of the universe has real significance in the cosmic imagination of the authors/redactors of the HB. The cosmic centre symbolises order, structure, salvation, and life. The outer limits, whether horizontally (the waters of chaos) or vertically (the depths of Še'ôl) symbolise chaos, disorientation, persecution,

20 Soja, Thirdspace, 68.

21 Leonard L. Thompson, Introducing Biblical Literature: A More Fantastic Country (Engelwood Cliffs: Prentice-Hall, 1978), 13.

22 Thompson, Introducing Biblical Literature, 53.

23 Thompson, Introducing Biblical Literature, 54.

24 Thompson, Introducing Biblical Literature, 54.

25 For an overview of biblical worldview(s), cf. Bernd Janowski, "Das biblische Weltbild: Eine methodologische skizze," in Das biblische Weltbild und seine altorientalischen Kontexte (ed. Bernd Janowski and Beate Ego; Tübingen: Mohr Siebeck, 2001), 3-26; Angelika Berlejung, "Weltbild/Kosmologie," in Handbuch theologischer Grundbegriffe zum alten und neuen Testament (ed. Angelika Berlejung and Christian Frevel; Darmstadt: Wissenschaftliche Buchgesellschaft, 2006), 65-72.

26 Thompson, Introducing Biblical Literature, 59.

27 Nicolas Wyatt, Space and Time in the Religious Life of the Near East (Sheffield: Sheffield Academic Press, 2001), 35-40.

28 Thompson, Introducing Biblical Literature, 54-65. 
and death. ${ }^{29}$ To be at-centre implies to be in the presence of YHWH, to live in harmony with YHWH and the covenantal community, to experience שלום, indeed, to be in heaven. ${ }^{30}$

In the "world of words produced by the text" the poets of the Psalms provide readers with a "point of view/focus/spatial perspective" which reveals their "ideological stance." 31 Simply stated that ideological stance can be summarised as the belief in YHWH, the Creator-King, as "the universal God of heaven" who "determines whether one is off- or at-center." 32 The "rootmetaphor" of YHWH as Creator-King allows the poets to imagine a new reality, a 'counterspace' as space of resistance to a "real" world where they were confronted by suffering and oppression. ${ }^{33}$ Metaphors are intrinsically related to the world of words produced by the text as we "use metaphors all the time in order to say something about things we know little about." ${ }^{34}$ Metaphors allow us to "use the conventional wisdom associated with one context to serve as the screen or grid through which we see the other context," hence "metaphor

29 Wayne Horowitz, Mesopotamian Cosmic Geography (MCiv 8; Winona Lake, Indiana: Eisenbrauns, 1998), xii; Annette Krüger, "Himmel - Erde - Unterwelt: Kosmologische Entwürfe in der poetischen Literatur Israels," in Das biblische Weltbild und seine altorientalischen Kontexte (ed. Bernd Janowski and Beate Ego; Tübingen: Mohr Siebeck, 2001), 65-83.

30 Bernd Janowski, "Die heilige Wohnung des Höchsten: Kosmologische Implikationen der Jerusalemer Tempeltheologie," in Gottesstadt und Gottesgarten: Zu Geschichte und Theologie des Jerusalemer Tempels (ed. Othmar Keel and Erich Zenger; QD 91; Freiburg: Herder, 2002), 24-68; Gert T. M. Prinsloo, "Š e' ôl $\rightarrow$ Yerûšālayim $\leftarrow$ Šāmayim: Spatial Orientation in the Egyptian Hallel (Psalms 113118)," OTE 19 (2006): 739-60; James L. Mays, Psalms (IBC; Louisville, Ky.: John Knox Press, 1994), 75. The temple was regarded as heaven upon earth. See Janowski, "Die heilige Wohnung," 26-27.

31 Gert T. M. Prinsloo, "Place, Space and Identity in the Ancient Mediterranean World: Theory and Practice with Reference to the Book of Jonah," in Place, Space and Identity in the Ancient Mediterranean World (vol. 5 of Constructions of Space; ed. Gert T. M. Prinsloo and Christl M. Maier; LHBOTS 576; New York: Bloomsbury T\&T Clark, 2013), 3-25 (7).

32 Prinsloo, "Place, Space and Identity," 25. According to Tryggve N. D. Mettinger, In Search of God: The Meaning and Message of the Everlasting Names (trans. F. H. Cryer; Philadelphia: Fortress, 1978), 92 the notion of YHWH as King can probably be called "the center of the Old Testament understanding of God."

33 Mettinger, In Search of God, 92 defines a root metaphor as "a metaphor that serves as a basic analogy or model; it is used to describe the nature of the world" and "feeds a whole family of extended metaphors; it comprises the genetic code for a broad complex of ideas."

34 Sallie M. TeSelle, Speaking in Parables: A Study in Metaphor and Theology (Philadelphia: Fortress, 1975), 43. 
belongs more in the realm of faith and hope than in the realm of knowledge." Through the grid of the "YHWH as Creator-King" metaphor the poets of the Psalms could imagine the temple in Jerusalem as the centre of their universe, the meeting point between heaven and earth, the place where one can truly be at-centre. They invite us to read "from centre" and expect us by doing so to arrive "at centre." 36

Suffering in the Psalter is described in spatial terms. Causes of suffering can be enumerated, ${ }^{37}$ but ultimately it implies separation from YHWH and his saving presence at-centre. The vertical and horizontal symbolism with Jerusalem/Zion as the centre of the universe "refers to an existential perspective rather than a geographical location,",38 to a lived experience "imagined" by the poet rather than a "physical" place or "abstract" space. Poems create a world of words that is related to the "real" world, but not identical to it. Bernd Janowski used the metaphor of a house to indicate that the Book of Psalms in the end can be regarded as a house or temple "nicht aus Steinen, sondern aus Worten (templum spirituale), mit dem Proömium Ps 1-2 als weitem 'Eingangsportal' . . . und mit dem Schlußhallel Ps 146-150 als klangvollen 'Schlussstein.,"39

For a number of reasons Ps 11 is an excellent case study of the spatial ideology of the Psalter in general and Pss 3-14 as the first deliberate collection of poems in the Book of Psalms in particular. First, it contains spatial terminology on both the horizontal and vertical levels. ${ }^{40}$ Second, the poem oscillates between movement between spaces and quiet confidence in space. ${ }^{41}$ Third, the

35 TeSelle, Speaking in Parables, 43.

36 Mettinger, In Search of God, 92 remarks that "the Lord as 'King' is a metaphor that generates other, related metaphors; it supports an entire tree and its attendant ramifications. Among these ramifications is the notion of the temple as God's royal dwelling - God's 'palace."'

37 Moore, Investigation, 8-59 lists as causes of suffering: loneliness and the experience of isolation (Ps 12; 25) and abandonment (Ps 13; 22; 42-43; 44; 55; 74); persecution by enemies (Ps 54; 94; 109; 140) accompanied by torment (Ps 137) and the denial of YHWH's existence and ability to save (Ps 14); anxiety caused by personal sin (Ps 51), disease (Ps 38), stress (Ps 31) or fear of death (Ps 88).

38 Thompson, Introducing Biblical Literature, 64.

39 Bernd Janowski, "Ein Tempel aus Worten: Zut theologischen Architektur des Psalters," in The Composition of the Book of Psalms (ed. Erich Zenger; BETL 238; Leuven: Peeters, 2010), 279-306 (305).

40 Cf. חסיתי "I took refuge" (1b); המו־אפל "mountain" (1c); "שר "from darkness" (2c); "the foundations" (3a); היכל קדשות "his holy temple" (4a); שמים "heaven" (4b).

41 Movement is suggested by the command to flee (1c), the hunting metaphor (2abc), the destruction of foundations (3a) and the raining of fire and brimstone upon the wicked (6b). Quiet confidence is suggested by the poet's confession that he takes refuge in YHWH (1a), YHWH's presence in the temple and upon his heavenly throne (4ab), and his scrutinising of mankind (4cd; 5abc). 
binary pair "off-centre/at-centre" is present in several verses. ${ }^{42}$ Fourth, the poem is not a lament where "separation" terminology is to be expected, but a confession of faith (11:1). I will argue that a spatial reading provides a key to unravel also this poem's interpretational challenges. ${ }^{43}$ Fifth, the psalm illustrates the direct spatial link between Jerusalem/Zion/temple on the one hand and YHWH's kingship on the other hand (11:4). ${ }^{44}$ Psalm 11:4 occurs at the centre of the poem and invites us to read "from centre" in a reality where "the foundations" are being destroyed (11:3) and suffering is never far from the poet's mind (11:2).

\section{PSALM 11: INTRA- AND INTERTEXTUAL PERSPECTIVES}

\section{$1 \quad$ Introductory Remarks}

Psalm 11 is a "marginal" poem that received little attention in the history of Psalms research. ${ }^{45}$ Compared to the lingering beauty of Pss 8, 19 or 23 it seems to be "just another psalm, rather conventional and in no way outstanding in thought, form or literary merit."46 Psalm 11 confronts exegetes with difficult

42 Being at-centre is suggested by חסיתי "I took refuge" (1b); the image of YHWH in his holy temple and on his heavenly throne (4ab); the restoration of the righteous to their proper location in the presence of YHWH (7ab). Being off-centre is suggested by the command נודי הרכם "flee your mountain" (1c); the image of the righteous as a hunted animal (2abc); the destruction of foundations (3ab).

43 I investigated the theme of suffering and spatiality in a study of Ps 13, a classic example of an individual lament. I argued that "the individual spatial experience of a sufferer provides a key to a holistic interpretation of individual laments" and that "these laments draw heavily upon spatial language . . . to give voice to feelings of estrangement and divine and social distance and absence on the one hand, and the longing for restoration of relationships and divine and social presence on the other hand." Cf. Gert T. M. Prinsloo, "Suffering Bodies - Divine Absence: Towards a Spatial Reading of Ancient Near Eastern Laments with Reference to Psalm 13 and An Assyrian Elegy (K 890)," OTE 26 (2013): 773-803 (784).

44 Studies devoted to the kingship of YHWH usually concentrate on poems containing so-called Zion theology (Pss 46-48) or the YHWH mlk psalms (Pss 93-99), cf. Marc Z. Brettler, God is King: Understanding an Israelite Metaphor (JSOTSup 76; Sheffield: JSOT Press, 1989); Shawn W. Flynn, YHWH is King: The Development of Divine Kingship in Ancient Israel (VTSup 159; Leiden: Brill, 2014). Mettinger, In Search of God, 93 indicates that the notion of God as King "lies beneath the surface of numerous texts, even of some that do not use 'king,' 'to rule,' 'throne,' and so forth."

45 Cf. the bibliographies in Erhard S. Gerstenberger, Psalms Part I with an Introduction to Cultic Poetry (FOTL 14; Grand Rapids, Mich.: William B. Eerdmans, 1988), 80; Hans-Joachim Kraus, Psalms 1-59 (trans. H. C. Oswald; Minneapolis: Augsburg, 1988), 201; Oswald Loretz, Psalmstudien: Kolometrie, Strophik und Theologie ausgewählter Psalmen (BZAW 309; Berlin: Walter de Gruyter, 2002), 104-5; Peter Craigie, Psalms 1-50 (WBC 19; Nashville: Thomas Nelson, 2004), 131.

46 Julian Morgenstern, "Psalm 11," JBL 69 (1950): 221-231 (221). 
textual and interpretational problems. ${ }^{47}$ Text critical problems in vss. 1c and $6 \mathrm{a}$ gave rise to imaginative reconstructions of the text. ${ }^{48}$ Interpretational problems abound. In $1 \mathrm{~b}$ a group of people advise the poet to flee. He quotes them in $1 \mathrm{~d}$, but it is the quote restricted to $1 \mathrm{~d}$ or does it run through to $2 \mathrm{c}$ or to $3 b ?^{49}$ Is the quoted advice given by friends or enemies? ${ }^{50}$ What is the meaning of the rare noun צדיק in 3a and 5a refer to YHWH or a righteous person? $?^{51}$ The poem is classified as a prayer of confidence or trust, ${ }^{52}$ but its Sitz im Leben is difficult to determine. Under what circumstances do the first person speaker who associates himself with the "righteous" (3b; 5a) and the "upright at heart" $(2 \mathrm{a} ; 7 \mathrm{~b})$ utter the poem? ${ }^{53}$

47 Hossfeld and Zenger, Psalmen 1, 88-92.
48 Isaiah Sonne, "Psalm 11," JBL 68 (1949): 241-5; Morgenstern, "Psalm 11," 221-
31.
49 For an overview of these views, cf. Peter Riede, Im Netz des Jägers: Studien zur Feindmetaphorik der Individualpsalmen (WMANT 85; Neukirchen-Vluyn: Neukirchener Verlag, 2000), 370.

50 Some regard it as advice given by caring friends lacking in faith, cf. Hermann Gunkel, Die Psalmen (HKAT II/2; Gottingen: Vandenhoeck and Ruprecht, 1929), 41. Others regard it as mocking advice given by the wicked mentioned in 11:2, cf. Nico A. van Uchelen, 1-40 (vol. 1 of Psalmen; POut; Nijkerk: Callenbach, 1979), 74-5; Harris Birkeland, Die Feinde des Individuums in der israelitischen Psalmenliteratur: Ein Beitrag zur Kenntnis der semitischen Literatur- und Religionsgeschichte (Oslo: Grøndahl, 1933), 239-42. Some regard the wicked as foreign enemies, cf. Moses Buttenwieser, The Psalms (Chicago: University of Chicago Press, 1938]) 442; while others see them as godless Israelites, cf. Friedrich Baethgen, Die Psalmen (HKAT II/2; Göttingen: Vandenhoeck and Ruprecht, 1904), 30.

$513 \mathrm{~b}$ can be translated "what can the Righteous One / a righteous person do?" 5ab can be translated "YHWH is righteous, he examines the wicked ..." or "YHWH - he examines the righteous, but the wicked... he abhors" or "YHWH - he examines the righteous and the wicked, and the one who loves violence he abhors." Cf. Paul R. Raabe, "Deliberate Ambiguity in the Psalter," JBL 110 (1991): 213-27 (222-3); Robert C. Bratcher and William D. Reyburn, A Translator's Handbook on the Book of Psalms (HTrans; New York: UBS), 111-3.

52 Hermann Gunkel and Joachim Begrich, Einleitung in die Psalmen: Die Gattungen der religiösen Lyrik Israels (HKAT II; Göttingen: Vandenhoeck and Ruprecht, 1933), 254-5; John D. W. Watts, "Psalms of Trust, Thanksgiving, and Praise," RevExp 81 (1984): 395-406 (395-6).

53 The first person speaker has been identified: (1) as an individual pious person confessing his trust in YHWH, cf. Hossfeld and Zenger, Psalmen 1, 89; (2) a falsely accused seeking asylum in the temple, cf. Kraus, Psalms 1-59, 201; William H. Bellinger, "The Interpretation of Psalm 11," EvQ 56 (1984): 95-101; Klaus Seybold, Die Psalmen (HAT I/15; Tübingen: Mohr, 1996), 60; (3) an accused taking part in a cultic ritual to prove his/her innocence, cf. Hans Schmidt, Die Psalmen (HAT 15; Tübingen: Mohr, 1934), 20; Arthur Weiser, The Psalms (trans. H. Hartwell; OTL; London: SCM, 1962), 155; (4) an accused taking part in an ordeal, e.g. drinking a cup 
In this study I argue that the centrality of the related concepts temple/heaven that permeate the Psalter lies at the heart of the poem (cf. 11:4). ${ }^{54}$ Separation from this centre, whether real or imagined, implies suffering. A reading from this centre (11:4) elucidates the contrast between the poem's beginning (11:1-3) and end (11:5-7). The poet's imagined proximity to YHWH in his temple and thus in heaven determines his ability to imagine a new reality, a "counterspace" as space of resistance to a "real" world where he is confronted by suffering.

\section{$2 \quad$ Psalm 11: Text and Translation}

\begin{tabular}{|c|c|c|c|c|c|}
\hline \multicolumn{3}{|c|}{ Superscript 1} & למנצח לדוד & $1 \mathrm{a}$ & To the conductor. Of David. \\
\hline \multirow{3}{*}{\multicolumn{2}{|c|}{$1 \mathrm{~A}$}} & 2 & 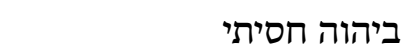 & $1 b$ & With YHWH I took refuge, \\
\hline & & & איך תאמתו לנפשי & $\mathrm{c}$ & how can you tell me: \\
\hline & & & נַודי הרכם צפור & d & "Flee your mountain, little bird!" \\
\hline \multirow{5}{*}{\multicolumn{2}{|c|}{ B }} & & כי הנה הרשעים ידרכון קשת & $2 \mathrm{a}$ & If, indeed, the wicked bend the bow, \\
\hline & & & כוננו חצם על-יתר & $\mathrm{b}$ & set their arrow upon the string, \\
\hline & & & לירות במו־אפל לישרי־לב & $\mathrm{c}$ & to shoot from darkness \\
\hline & & 1 & בוי & & at the upright in heart, \\
\hline & & 4 & צדיק מה־פעל & $\begin{array}{r}3 \mathrm{a} \\
\mathrm{b}\end{array}$ & $\begin{array}{l}\text { a righteous person - } \\
\text { what can he accomplish? }\end{array}$ \\
\hline \multirow{4}{*}{\multicolumn{2}{|c|}{$2 \mathrm{~A}$}} & 5 & יהוה בהיכל קדשו & $4 a$ & YHWH is in his holy temple, \\
\hline & & & יהוה בשמים כסאו & b & $\begin{array}{l}\text { YHWH - in the heavens } \\
\text { is his throne. }\end{array}$ \\
\hline & & 6 & עיניו יחזו & $4 c$ & His eyes observe, \\
\hline & & & עפעפיו יבחנו בני אדם & d & his eyelids examine the sons of man! \\
\hline \multirow[t]{3}{*}{3} & A & 7 & 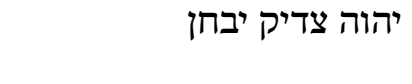 & $5 a$ & $\begin{array}{l}\text { YHWH - a righteous person } \\
\text { he examines, }\end{array}$ \\
\hline & & & ורשע וז & $\mathrm{b}$ & $\begin{array}{l}\text { but a wicked person } \\
\text { and one who loves violence }\end{array}$ \\
\hline & & & & 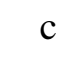 & he passionately abhors. \\
\hline
\end{tabular}

of wine to lower his defenses and force him/her to tell the truth, cf. Walter Beyerlin, Die Rettung der Bedrängten in den Feindpsalmen der Einzelnen auf institutionelle Zusammenhänge untersucht (FRLANT 99; Göttingen: Vandenhoeck and Ruprecht, 1970), 101-5; Karel van der Toorn, "Ordeal Procedures in the Psalms and the Passover Meal," VT 38 (1988): 427-45 (437-42); (5) someone in danger of becoming the victim of a black magic ritual known as "the hunting of the soul," cf. Morgenstern, "Psalm 11," 223-4. For a critical evaluation of such cultic interpretations, cf. Philip S. Johnston, "Ordeals in the Psalms?" in Temple and Worship in Biblical Israel: Proceedings of the Oxford Seminar (ed. John Day; London: T\&T Clark, 2007), 271-91.

54 Susan Gillingham, "The Zion Tradition and the Editing of the Hebrew Psalter," in Temple and Worship in Biblical Israel: Proceedings of the Oxford Seminar (ed. John Day; London: T\&T Clark, 2007), 308-41; Susan Gillingham, "The Levitical Singers and the Editing of the Hebrew Psalter," in The Composition of the Book of Psalms (ed. Erich Zenger; BETL 238; Leuven: Peeters, 2010), 91-123. 
786 Prinsloo, "Suffering as Separation," OTE 28/3 (2015): 777-806

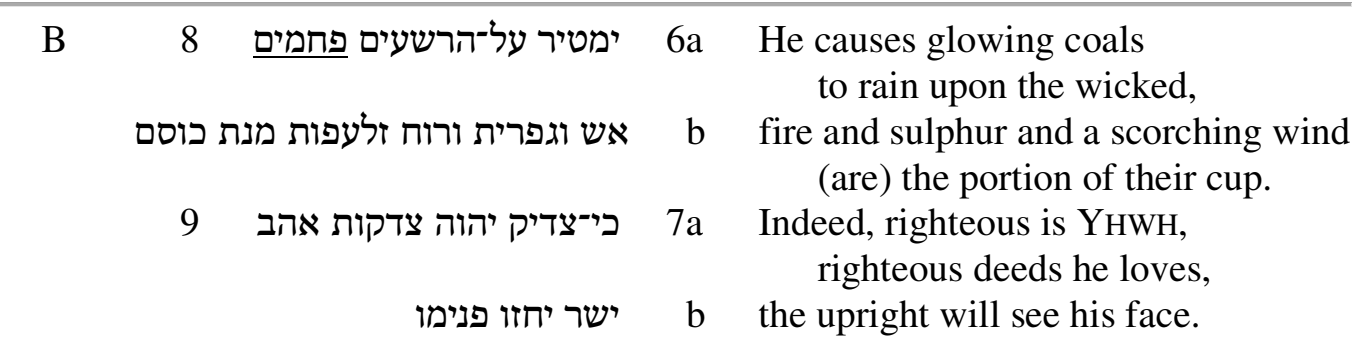

\section{$3 \quad$ Psalm 11: Textual and Exegetical Notes}

A number of cola in the text and translation represented above need elucidation. I discuss textual and interpretational problems of those cola before I turn to a holistic interpretation and spatial reading of the poem.

\section{1b ביהוה חסיתי With YHWH I took refuge}

חסה qal "to take refuge" occurs 42 times in the HB, 25 times in the Psalter. Jerome F. D. Creach argues that the high frequency of occurrences of the word and related terms in the Psalter indicates "that the Psalter contains a 'refuge piety,' in which dependence upon Yahweh is the supreme virtue. ${ }^{, 56}$ Refuge can be taken with people (Judg 9:15; Isa 30:2; Prov 14:32), but especially with YHWH. The verb is used in conjunction with the metaphor of YHWH as rock (צור; Deut 32:37; 2 Sam 22:3; Ps 18:3), shield (מגן; 2 Sam 22:31; Ps 18:3; Prov 30:5), stronghold (מעוז; Nah 1:7; Ps 144:2). One can take refuge under YHWH's "wings" (תחת כנפיו; Ruth 2:12; Ps 36:8; 57:2; 61:5; 91:4) or at his "right hand" (Ps 17:6). "Zion" (ציון; Isa 14:32), "my holy mountain" (הר־קדשי; Isa 57:13) and "the name of YHWH" (שם יהוה; Zeph 3:12) are locations where refuge can be found. Most often the psalmist simply states that he takes refuge in YHWH $(2: 12 ; 5: 12 ; 7: 2 ; 11: 1 ; 16: 1 ; 25: 20 ; 31: 2,20 ; 34: 9,23 ; 37: 40 ; 57: 2 ; 64: 11 ; 71: 1$; $118: 8,9 ; 141: 8)$. In Ps 11 refuge is to be found in the temple (11:4ab). Creach argues that חסה "communicates an attempt to acquire shelter, and thus, was perhaps best suited to express the security provided by the temple."

1d נודי הרכם צפור "Flee your mountain, little bird!"

A $K^{e} t \hat{\imath} b-Q^{e} r \bar{e}$ ' variant occurs with the verb נוד "to sway, be aimless, be home-

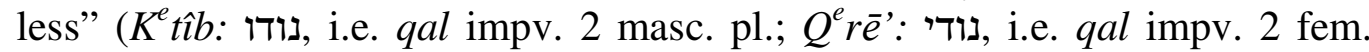
sg.). There is a discrepancy in person, gender and number between the 2 masc. pl. suffix (הרכם "your mountain") and the fem. sg. noun "bird." The

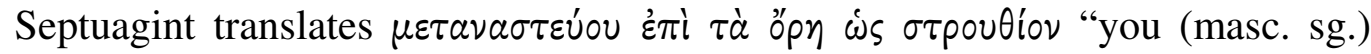

55 For the distribution of the word and other terms related to the semantic field "refuge" in the Psalter, cf. Jerome F. D. Creach, Yahweh as Refuge and the Editing of the Hebrew Psalter (JSOTSup 217; Sheffield: Sheffield Academic Press, 1996), 37-43.

${ }_{57}$ Creach, Yahweh as Refuge, 48.

57 Creach, Yahweh as Refuge, 30. 
must flee to the mountain like a bird." Many commentators emend the Hebrew to read נוד הר כמו־צפור "flee to the mountain like a bird.",58

The $Q^{e} r \bar{e}$ ' implies that צפור is the subject of a 2 fem. sg. impv. נודי "you (fem. sg.) must flee your mountain, bird!" נוד denotes shaking/swaying/fleeting movement. It indicates the shaking of the head as sign of sympathy (Isa 51:19; Jer 15:5; 16:5; 22:10; 31:18; 48:17; Nah 3:7; Ps 56:9; 69:21; Job 2:11; 42:11), or scorn (Jer 18:16; 48:27); instability/untrustworthiness, e.g. the swaying of a reed in water (1 Kgs 14:15), a hut in the wind (Isa 24:20), or an Israelite serving idols (Jer 4:1); loss of security, being without solid foundation, home or refuge. Cain became a "roamer and wanderer" (נע ונד; Gen 4:12, 14). YHWH promised not to make the Israelites' feet wander (להניד) from the promised land if they remain faithful to him (2 Kgs 21:8). In Ps 36:9 the petitioner pleads that the hand of the wicked should not "drive me away" (אל־תנדני) from YHWH. In Jer 49:30 the inhabitants of the Hasor are urged: "Flee, flee quickly ..." (סנדו נדו מאד (מאד 50:3 Babylon is warned that "both man and animals will flee, depart" (מאדם ועד־בהמה נדו הלכו) and in 50:8 her inhabitants are urged: "Flee from Babel!" (נדו מתוך בבל נורוּו).

is problematic because the antecedent of the 2 masc. pl. suffix is not immediately apparent, but presumably it should be associated with the ישרי־לב "upright in heart" mentioned in $2 \mathrm{c}$. If the $Q^{e}$ re ' reading is retained, $1 \mathrm{~d}$ implies that the poet associates with this group. הר "mountain" is usually taken as the place of refuge for the fleeing bird. Many commentators indicate that caves in the Judean mountains are natural places of refuge and security for humans and animals alike; cf. 1 Sam 24:26; Ps 30:8; 46:3; 50:11; 104:18. ${ }^{59}$ It is difficult, however, to explain why הר occurs in the singular as if a particular mountain is meant. ${ }^{60}$ I regard הרכם as an accusative of place after a verb of motion (cf. Deut 33:19) ${ }^{61}$ and maintain that the text is deliberately ambiguous. The direction of flight can be to a mountain or from a mountain. In either case, the advice amounts to leaving YHWH as source of refuge. If the "bird" flees to a mountain, it would imply leaving the presence of YHWH as source of refuge (1b). If the "bird" flees from a mountain, which would indicate the temple mountain as place of refuge (1b), it would amount to the same folly. The psalmist proclaims that he takes refuge in YHWH (1b), but his adversaries

58 Julius A. Bewer, "Text-critical Suggestions on Hosea xii. 1, iv. 4, iv.8; Isaiah xiv. 12 b; Psalm xi. 1," JBL 21 (1902): 108-114 (113-4); Weiser, Psalms, 154; Bellinger, "Interpretation," 95; Creach, Yahweh as Refuge, 45.

59 Charles A. Briggs and Emilie G. Briggs, A Critical and Exegetical Commentary on the Book of Psalms (vol. 1; ICC; Edinburgh: T\&T Clark, 1906), 89; Van Uchelen, Psalmen 1, 75-6.

60 Walter Brueggemann and William H. Bellinger, Psalms (NCamBC; Cambridge: Cambridge University Press, 2014), 68 translates the colon without any explanation by "Flee like a bird to the mountains."

61 GKC $\$ 118 f$; Baethgen, Psalmen, 30. 
scornfully advise him to flee his place of refuge, derisively called הרכם "your mountain," that is a reference to Zion/the temple as place of refuge (cf. 4ab) for the ישרי־לב "upright in heart" (2c).

צפור "bird" occurs 47 times in the HB. It often refers to birds as a category of animals (cf. Gen 7:14; Deut 4:17; Ezek 17:23; Pss 8:9; 104:17; 148:10), but evidently Ps 11:1d has a more specific use of the word in mind. In two texts צפור is used as parallel to דרור "swallow," thus to a small bird, often translated with "sparrow." In Ps 84:4 a petitioner yearns to visit the house of YHWH in Zion where "even the sparrow (צפור) has found a home, and the swallow (דרור) a nest for herself, where she may have her young - a place near your altar (מזבחותיך), YHWH Almighty . ..." The image is one of little birds find a resting place at the altar, a place associated with asylum, safety, and contact with YHWH. In Prov 26:2 an undeserved curse is likened to "a fluttering sparrow or a darting swallow" (כצפור לנוד כדרור לעוף), it does not come to rest. צפור refers to the fluttering of a small bird without a place to alight. Significantly the verb used to describe this restless fluttering is Such a bird is prone to become the prey of a hunter (cf. Amos 3:5; Ps 124:7; Prov 6:5; 7:23; Qoh 9:12). The hunter image plays an important role in Ps 11 as well (cf. 2abc; 6a).

Contrary to the prevailing interpretation that $1 \mathrm{~d}$ contains advice to the petitioner to flee to a mountain/the mountains like a bird, I interpret the colon as advice to the petitioner, derisively called "birdie," 62 to flee from the safety of YHWH's mountain. In Prov 27:8 a person who "wanders (נודד) from his home" is likened to a "bird that stays from her nest" (כצפור נודדת מן־כנה). The wicked's derisive advise in similar fashion implies that the petitioner (and the "upright in heart") should flee because contrary to the petitioner's confession in $1 \mathrm{~b}$, no refuge is actually to be found with YHWH in the temple. Ps 11:1bcd refutes this advice and confirms trust in YHWH's presence.

2c לירות במו־אפל לישרי־לב to shoot from darkness at the upright in heart,

The hunters lie in wait in darkness (אפל) to shoot (לירה ; quות) "to shoot") at their unsuspecting victims. אפל "darkness" occurs only 10 times in the HB (Isa 29:18; Amos 5:20; Pss 11:2; 91:6; Job 3:6; 10:22 (X2); 23:17; 28:3; 30:26) in parallelism with חשד "darkness" (cf. Isa 29:18; Amos 5:20; Job 3:5-6; 23:17; 28:3); צלמות "gloom" (cf. Job 3:5-6; 10:22; 28:3); עיפתה "darkness" (Job

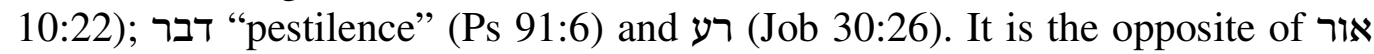
"light" (Amos 5:20; Job 30:26) and נגה "gleam" (Amos 5:20). As such אפל is associated with Sheol and thus symbolizes grave danger, evil, even death.

The unsuspecting victims are the ישרי-לב "upright at heart" (cf. Pss 7:11; $32: 11 ; 36: 11 ; 64: 11 ; 94: 15 ; 97: 11)$. Psalm 125:4 contains a slightly variant

62 Baethgen, Psalmen, 30. 
form ישר to the upright in their hearts.” In Ps 119:7 לישרים בלבותם appears in

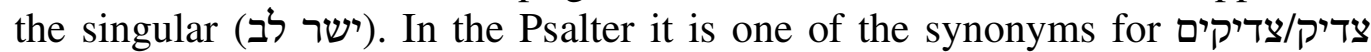
"the righteous." ישר is repeated in 7b.

3a בי השתות יהרסון if the foundations are destroyed

Psalm 82:5 uses different words (cf. ימוטו כל־מוסדי ארץ "all the foundations of the earth are shaken"), but contains a similar image. ${ }^{63}$ "שרת is a rare noun. It occurs as personal name ("Seth"; cf. Gen 4:25, 26; 5:3, 4, 6, 7, 8; Num 24:17; 1 Chr 1:1). Only in four instances (2 Sam 10:4; Isa 19:10; 20:4; Ps 11:3) appears as a noun. In Isa 20:4 it occurs in the singular in a context where the prophet describes Egyptians being deported by Assyria "naked, barefoot and bare of buttock (חשופי שת)." In 2 Sam 10:4 the plural שתות is used in similar fashion. The Ammonite king, Hanun, shames David's messengers by shaving off "half of each man's beard" and cutting off "their garments in the middle at their buttocks (שתותיהם)," thus baring the lower body. In Isa 19:10 שתתיה is regarded as not intelligible and emended to שתיתיה/שותיה, probably to be derived from a verbal root שתה "to weave" and to be translated with "her weavers." The noun is probably derived from שית "put, set" (cf. MHeb. שית "foundation"; Ug ̌̌t "foundation, base"; Akk ǐ̌du "foundation"; Syr 'eštā "bottom, floor). ${ }^{64}$ in colon 3a should probably be understood in the sense of "foundations," usually interpreted as the foundations of society, i.e. security, community, justice, religion. ${ }^{65}$ Read in conjunction with colon $1 \mathrm{~d}$, it can be argued that the "foundations" ultimately are the "foundations" of "your mountain." Verse 4 makes it clear that the mountain is none other than Zion where the temple is located. Should these foundations be destroyed, one would enter the realm of death (already suggested in colon 2c). Significantly, in Ps 84:4 the "sparrow finds a house" (צפור מצאה בית) and the "swallow a nest" where "she may put her young ones" (דרור קן לה) (אשר־שתה אפרחיה). That spe-

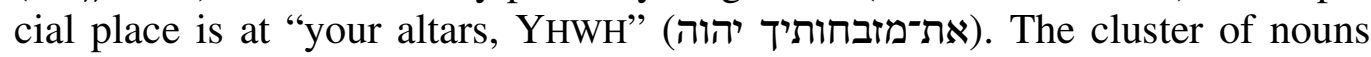
(מזבח ,בית, צפור) referring to a bird finding a house at the altar, as well as the verb (שית) indicating safety, stability and shelter are reminiscent of the vocabulary of Ps 11:1-3. מה in colon 3b suggests that the strophe (2a-3b) should be read as a rhetorical question. The psalmist contemplates the advice received in 1bcd: if, indeed, the wicked are on the verge of annihilating the upright at heart, if the very foundations of the poet's faith are shattered, all efforts of the צדיק seem to be in vain.

63 Kraus, Psalms 1-59, 202.

64 Cf. the discussion in HALOT.

65 Weiser, Psalms, 156. 
In spatial terms, there is a direct relationship between YHWH's "holy temple" (היכל קדשו) and "his throne" (בסאו) in "heaven" (בשמים). ${ }^{66}$ The "throne" is a symbol of YHWH's kingship and his authority to judge. ${ }^{67}$ The terminology suggests that YHWH is the ultimate king. To be in his gracious presence implies to be "at-centre" and to experience peace. Creach indicates that "the refuge metaphor is understood perhaps only when it is located in a larger metaphorical schema, namely, in relation to the figure of Yahweh's kingship." ${ }^{, 68}$ There is thus a direct relationship between the poet's confessions of faith in 1a and $4 a b .^{69}$

6a ימטיר על־הרשעים פחמים He causes glowing coals to rain upon the wicked

The interpretation of colon $6 \mathrm{a}$ is controversial and the reading of MT in dispute. פחים מטר he hip 'il "to cause to rain" in conjunction with the noun "snares/nets" as object (6a) seems problematic as פח is associated with a "snare" set on the ground to entangle feet (cf. Job 22:10; Ps 119:10; 142:4; Prov 22:5; Hos 5:1). It occurs in parallelism with פחת "pit" (cf. Isa 24:17, 18; Jer 48:43, 44); שיחה "trap" (Jer 18:22); מוקש "snare" (Jos 23:23; Ps 69:23; 140:6; 141:9; Isa 8:14; Amos 3:5); צמים "traps" (Job 18:9). It is specifically associated with the actions of bird trappers (Ps 91:3; 124:7; Prov 7:23; Qoh

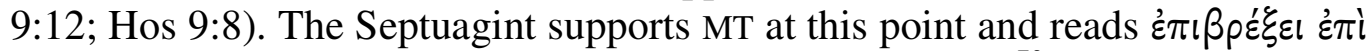

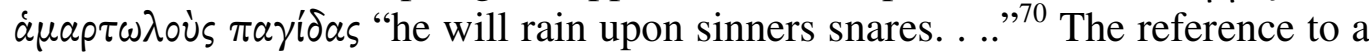
bird (2c) and hunting (3abc) makes the reference to פחים at least conceivable.

The following אש וגפרית "fire and sulphur" (6b) occur in contexts where YHWH destroys his enemies and is reminiscent of theophanic language (cf. Gen

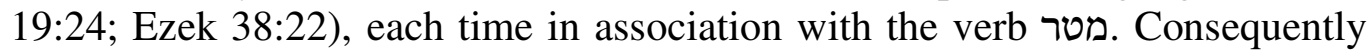
11:6ab is often emended to ימטר על־רעים פחמי אש וגפרית "he causes to rain upon the wicked fiery coals and sulphur."

66 Brueggemann and Bellinger, Psalms, 69 state that "the two parallel lines at the same time offer a characteristic juxtaposition about the temple in Jerusalem and the dwelling of YHWH in heaven as a way of making a claim for Solomon's temple, and acknowledge that divine residence is not in the temple in Jerusalem but in heaven, beyond human patronage and domestication." For a similar image cf. $1 \mathrm{Kgs}$ 8:30.

67 Willem A. VanGemeren, Psalms (ExpBC 5; Grand Rapids: Zondervan, 1991), 133.

68 Creach, Yahweh as Refuge, 51.

69 Creach, Yahweh as Refuge, 52 states: "The refuge metaphor seems to communicate the comprehensive responsibility of ancient oriental kings to ensure the safety of their subjects through military and juridical means."

70 So also the Vulgate: pluet super peccatores laqueos "He will rain upon sinners

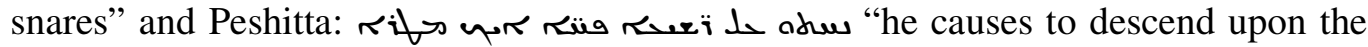
wicked a trap like rain."

71 Brueggemann and Bellinger, Psalms, 68 
Targum's יחית מטרין דפורענו על רשיעי מפחין דאשתא "he brings down the rain of vengeance upon the wicked, coals of fire." An important objection against the emendation is that it ignores the 'Ôlê $w^{e} y \hat{o} r \bar{e} d$ in MT פחים and thus compromises the poetic structure of the cola.

The noun פחם is rare, it occurs only in Prov 26:21; Isa 44:12; 54:16 and

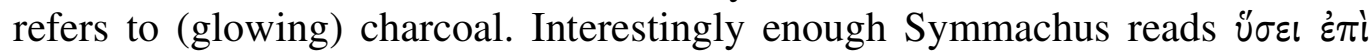

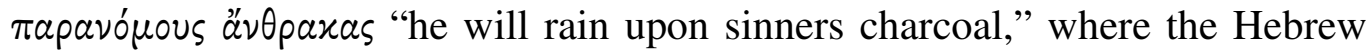
text then could have contained the reading פחמים "charcoal" instead of "nets." In Prov 26:21a פחם לגחלים ועצים לאשם "as charcoal to embers and as wood to fire" suggests that the פחסי "charcoal" ignites the "(burning) embers." The same suggestion might be present here. The פחמים "charcoal" raining upon the wicked (6a) ignite the אש וגפרית ורוח זלעפות "fire and sulphur and scorching wind" which bring about their destruction. I (hesitantly) accept this emendation due to the presence of other terms associated with a theophany. It is conceivable that an original פחמים could have become פחים through haplography.

6b אש וגפרית ורוח זלעפות מנת כוסם fire and sulphur and a scorching wind (are) the portion of their cup.

The expression אש וגפרית "fire and sulphur" is a word pair associated with YHWH's wrath and the annihilation of wicked people, for example the inhabitants of Sodom and Gomorrah (Gen 19:24) or the destruction of Gog (Ezek 38:22).

The noun זלעפה occurs only three times in the HB (Ps 11:6; 119:53; Lam 5:10). רוח זלעפות "scorching wind" refers to the sirocco (sharab/hamsin) the hot, dry wind blowing from the Arabian desert. ${ }^{72}$ Here it is a metaphor for אש וגפרית YHWH's wrath directed at the wicked. In spatial terms the expression ורוח זלעפות thus calls to mind total annihilation and the absence of YHWH's benevolent presence.

"the portion of their cup" might have its origin in the practice of the head of the household serving the drink to family members at mealtime, ${ }^{73}$ but the "cup" in YHWH's hand became a well-known metaphor for YHWH's wrath (cf. Ps 75:9; Isa 51:17, 21-23; Jer 25: 15-16; 51:17; Ezek 23:31$33){ }^{74}$

72 VanGemeren, Psalms, 133.

73 Weiser, Psalms, 157; Bellinger, "Interpretation," 98.

74 VanGemeren, Psalms, 133. 
7a כי־צדיק יהוה צדקות אהב Indeed, righteous is YHWH, righteous deeds he loves

Because YHWH is צדיק "righteous" he also loves צדקות "righteous deeds." This mutual relationship forms the basis of life. ${ }^{75}$

7b ישר יחזו פנימו the upright will see his face

פנימו "they will see his face" is a metaphor for living in YHWH's presence. ${ }^{76}$ Ancient Near Eastern kingship ideology also provides the background for the metaphor. When the king turns his face towards someone, that person finds favour in the eyes of the king. Numbers 6:24-26 serves as intertext for this colon. The so-called Aaronide blessing "articulates the face of YHWH as a source of blessing" and here the "temple is a vehicle for face-to-face encounter that yields for the qualified the gift of life."77

\section{$4 \quad$ Psalm 11: A Structural and Spatial Reading}

The first unit to be demarcated in Ps 11 is the superscript in vs. 1a למנצח לדוד "To the choirmaster. Of David"). It links Ps 11 with other Davidic poems in general and with the first Davidic collection comprising Book I (Pss 1-41) of the Psalter. ${ }^{78}$ This datum should not be glossed over. In the light of the "historical" superscripts in Pss 3:1, 7:1, 18:1 and 34:1 the "I" in Book I is the "imagined" or "ideal" David that is portrayed as a righteous sufferer with many enemies. He finds refuge and salvation in YHWH. ${ }^{79}$

The poem can be subdivided into three stanzas (1b-3b; 4a-d; 5a-7b). ${ }^{80}$ The theme of Stanza $1(1 b-3 b)$ is the threat posed to the upright/righteous by

75 Weiser, Psalms, 157.

76 Weiser, Psalms, 157.

77 Brueggemann and Bellinger, Psalms, 70.

78 Psalms 1-2 serve as introduction to the Psalter, introducing the important themes of (Torah) wisdom and (messianic) kingship, cf. Erich Zenger, "Der Psalter als Wegweiser und Wegbegleiter: Ps 1-2 als Proömium des Psalmenbuchs," in Sie wandern von Kraft zu Kraft: Aufbrüche, Wege, Begegnungen: Festgabe für Bischof Reinhard Lettmann (ed. Arnold Angenendt and Herbert Vorgrimler; Kevelaer: Butzon \& Bercker, 1993), 29-47. With the exception of Pss 10 and 33 all the poems in Book I (Ps 3-41) contain לדוד in the superscript, cf. Gerald H. Wilson, The Editing of the Hebrew Psalter (SBLDS 76; Chico, Calif.: Scholars Press, 198), 155-81.

79 Hubertus Schönemann, Der untreue Gott und sein treues Volk: Anklage Gottes angesichts unschuldigen Leidens nach Psalm 44 (BBB 157; Göttingen: V\&R Unipress, 2009), 187; Gilles Gerleman, "Der 'Einzelne' der Klage- und Dankpsalmen," VT 32 (1982): 33-49 (47) calls him "David als vorbildliches und schiksalbestimmendes exemplum."

80 Pierre Auffret, "Essai sur la structure littéraire du psaume 11," ZAW 93 (1981): 401-18. On formcritical grounds many commentators recognise two sections: the 
the wicked and the apparent helplessness of the righteous. The two groups are in direct confrontation. Two strophes can be demarcated.

Strophe 1A (1bcd) is a tricolon. יהוה is mentioned in 1b as a source of refuge, but plays no active role in the following cola. A first person speaker confesses that he takes refuge in YHWH (ביהוה חסיתי "in YHWH I take refuge"). The confession hints at the majestic presence and power of YHWH in 4a-d and the privilege of experiencing his presence in $7 \mathrm{~b}$. However, this experience of being at-centre is under dire attack. In 1c the poet engages in a direct confrontation with an unidentified group whom he addresses by means of a 2 masc. pl. verb. At the same time the poet refers to himself by means of a $1 \mathrm{sg}$. suffix ( איד "How can you tell me"). As indicated above, I do not regard 1c as the well-meant advice of the poet's friends. The context nowhere indicates the presence of friends. Verse 2 a rather suggests that the subject of the verb in $1 \mathrm{c}$ is the רשעים "wicked." This group of people give the poet mocking advice which he quotes in 1d: צפור "flee your mountain, (little) bird!" (fem. sg.) is the subject of the 2 fem. sg. impv. נודם and is used metaphorically for the poet. The 2 masc. pl. suffix (הרכם "your mountain") has no direct antecedent and most likely refers to the ישרי־לבם in 2c, the group with whom the poet associates. The poet refutes the advice given to him (1c) to flee from his safe haven (1d) in frantic flight like a scared bird, because he can only be atcentre in the presence of YHWH (1b). In the light of Stanza 2 (4a-d) that presence can be experienced in the temple. Therefore the poet cannot accept the advice to flee YHWH's mountain. It would amount to a conscious decision to move away from YHWH to a decidedly off-centre location. In spite of the poet's negative lived space, he clings to the promise of YHWH's protective presence.

Strophe $1 B(2 \mathrm{a}-3 \mathrm{~b})$ consists of a tricolon (2abc) and a bicolon (3ab). Both testify to negative space and the poet's off-centre situation. The poet contemplates the grave danger the wicked pose for the upright at heart and its consequences. In $2 \mathrm{abc}$ the metaphor of hunting is used to describe the increasingly dangerous position of the upright. 3 masc. pl. verbal forms/pronominal suffix describe actions of the wicked: 2a:כי הנה הרשעים ידרכון קשת"if, indeed, the wicked bend the bow;" 2 b כוננו חצם על-יתר "they set their arrow upon the string"). Both cola ominously suggest that the wicked is preparing for deadly slaughter while 2c expresses the purpose of their actions (לירות במו־אפל "upright in heart" are the target of the treacherous actions of the רשעים "wicked" and represent the group with whom the poet identifies. אפל "darkness" is an emotive term. It suggests the danger posed by death. The upright at heart stand

poet's desperation when he looks at society (1-3); his confidence when he looks to Yнwh (4-6; cf. Weiser, Psalms, 155-6; Hossfeld and Zenger, Psalmen 1, 89). The actors involved, the repetition of words, and spatial considerations rather suggest a tripartite division. 
on the brink of the abyss, in grave danger of being cut off from the presence of YHWH. It is confirmed in 3ab. 3a contains a 3 masc. pl. verb (כי השתות יהרסון "if the foundations are destroyed") referring to the treacherous actions of the wicked. In light of Ps 82:5 the rare noun השתות "the foundations" can be interpreted as a reference to the foundations of the established order in the cosmos. If these foundations are destroyed, chaos ensues. It is suggestive of a downward movement, sinking into the clutches of $\breve{S}^{e} \hat{o} l$. This leads to a desperate question in 3b, which contains a 3 masc. sg. verbal form (צדיק מה־פעל "what can a righteous person accomplish?"). The implication is that all efforts of the righteous is in vain.

Space in Stanza 1 (1b-3b) oscillates between positive (1b) and negative (1cd; 2abc) and ultimately becomes totally negative (3ab). A linear reading from Stanza 1 to Stanza 2 becomes a challenge to the upright in heart/righteous to lift their eyes from שמים שאול. The reality of enemies attacking the righteous has cosmic implications. It implies separation from YHWH on the horizontal (1d) and vertical (3a) levels and leads to the despairing question "what can a righteous person accomplish?" (3b). The question hints at the theodicy problem and stands in opposition to the quiet confidence expressed in $1 \mathrm{~b}$.

The central Stanza 2 (4a-d) provides the key for a spatial reading of Psalm 11. It consists of a single strophe (2A) containing two bicola (4ab; 4cd). YHWH is the sole actor in all four cola. The theme in 4ab is YHWH's presence in his holy temple (4a) and on his heavenly throne (4b). Two verbless clauses locate YHWH in his elevated position above the triumphs and tribulations of humanity, while 3 masc. sg. suffixes also refer to him (4a: יהוה בהיכל קדשו "YHWH is in his holy temple;" 4b: יהוה בשמים כסאו "YHWH - in the heavens is his throne"). The repetition of יהוה and the parallelism between 4ab emphasise YHWH's elevated position. YHWH is also the sole actor in 4cd. Two 3 masc. pl. verbal forms referring to YHWH's eyes/eyelids and two 3 masc. sing. suffixes confirm his royal stature and judicial control (4c: עיניו יחזו "his eyes observe;" 4d: עפעפיו יבחנו בני אדם "his eyelids examine the sons of man"). בני אדם refers to the whole of humanity. Humankind is no active role-player, only the object of YHWH's scrutiny. The verse emphasises that YHWH reigns as king of the universe. ${ }^{81}$

81 The image of YHWH observing humankind enhances the notion of YHWH as king and judge. He is fully aware of everything that happens upon earth. The totality of mankind (בני אדם) is subjected to his careful observing (חזה) and examining (בחן). בנים אדם 4n 4d performs double duty - it is also the object of the verb in 4c. Both verbs occur again: בחן in 5a, there specifically applied to the "righteous." חזיק occurs again in 7b. There the subject of the verb is ישר "the upright" - they are the people who will see "his face" (פנימו). The verbs thus occur in chiastic order: חזן - (4c) בחזה) (4d) (7b) (5a) - Tזה (7be extended chiasm conveys an important message: 
In spatial terms there is no "movement" in Stanza 2, just the quiet confidence in YHWH's control over everything from his elevated throne. YHWH sits high (positive space) and looks down. YHWH's presence has cosmic implications overshadowing all earthly forces intent upon separating the poet from YHWH. YHWH's presence at-centre transforms space into something entirely positive, although the use of בחן implies that YHWH's act of looking down might have negative implications.

If Stanza 1 challenges the righteous to lift their eyes from שמים to, Stanza 3 (5a-7b) describes a different situation altogether. The wicked were the main actors in Stanza 1, now YHWH acts and it implies movement to שאול for the wicked! The stanza consists of two strophes. Strophe $\mathbf{3 A}$ (5abc) is a tricolon. It describes the contrast between YHWH's examining of the righteous and his abhorrence of the wicked and the one who hates violence. In 5a a 3 masc. sg. verb refers to YHWH (יהוה צדיק יבחן "YHWH - a righteous person he examines"). The object of YHWH's examining is the צדיק "righteous" (cf. 3a). The 3 fem. sg. verb in 5c (with נפש נפשר as subject) and the 3 masc. sg. suffix also refer to his actions (שנאה נפשו "his innermost being abhors"). In 5b an internal parallelism identifies the object of YHWH's abhorrence as רשע ואהב חמס "a wicked person and one who loves violence" (cf. 2a). YHWH's looking down (4cd) implies the testing of the righteous (5a), resulting in a division of humanity into two groups. YHWH's judgment upon the wicked and those who love violence (5b) will be swift, because he passionately abhors them (5c)!

Strophe $3 B$ (6a-7b) consists of two bicola. It contains the same contrast between the wicked and the righteous, but in chiastic order compared to Strophe $3 \boldsymbol{A}$. In $6 \mathrm{ab}$ YHWH focuses his wrath upon the wicked. In 6a YHWH is the subject of a 3 masc. sg. verb, while the רשעים remain the object of his wrath (ימטר על־רשעים פחמים "he causes glowing coals to rain upon the wicked"). 6b continues this line of thought with a 3 masc. pl. suffix referring to the wicked "fire and sulphur and a scorching wind - the portion of their cup"). 7ab returns to the relationship between YHWH and the righteous. In 7 a both a verbless clause and a 3 masc. sg. verb refer to YHWH (כי־צ' (indeed, righteous is YHWH, righteous deeds he loves). Significantly, the root צדק is twice associated with YHWH - the righteous imitate the actions of their God (cf. 3b; 5a). A change of subject occurs in 7b. The upright are the subject of a 3 masc. pl. verb, while a 3 masc. sg. suffix refers to YHWH (ישר יחזו פנימו "the upright will see his face"). ישר "upright" have

YHWH's observation (4c) and examining of human beings (4d) lead to a clear division: He discerns between the righteous (5a) and the wicked (5b) to the benefit of the righteous - they are able to "see his face" (7b). The wicked, on the other hand, become the object of YHWH's abhorrence (5c) and they are annihilated (6ab).

82 Brueggemann and Bellinger, Psalms, 70 state: "It is surely of immense importance that the gaze of YHWH in verse 4 and the behold of the righteous in verse 7 use the 
already been encountered in 2c, while the root חזה also appears in 4d with YHWH as subject. 5a-7b thus implies a direct confrontation between YHWH and the צשיק/ישר "wicked," while the "righteous/upright" are the objects of his benevolent scrutiny and the people who may appear in his presence. They are, metaphorically speaking, transported from the depths of שאול to the lofty heights of שמים by taking refuge in YHWH (1b).

The repetition of key words is an important tool to link the three stanzas. Each stanza is introduced by the word ביהוה חסיתי), 1b; יהוה בהיכל קדשוה,

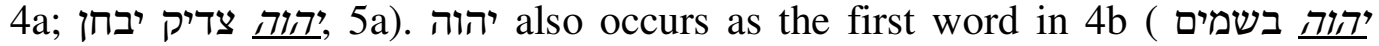

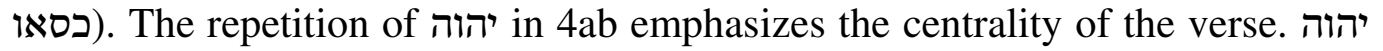
again appears in 7a (כי־צדיק יהוה צדקות אהב). The fivefold repetition of the divine name suggests that YHWH is the most important actor in the poem and Stanza 2 (4a-5b), where he is the only actor, the focal point of the entire poem.

Concepts associated with YHWH as a source of protective presence occur in all three stanzas. In $1 b$ the poet confesses that he takes refuge in YHWH (ביהוה חסיתי), therefore he refuses to flee "your mountain" (נודי הרכם צפור, 1d). In 4a the "mountain" is identified as YHWH's mountain where the "holy temple" (יהוה בהיכל קדשו) is to be found. It is the centre of the universe, the meeting point between heaven and earth, thus it can at the same time be described as his heavenly throne (יהוה בשמים כסאו, 4b). The concepts of mountain, temple and throne link Stanzas 1 (1b-3b) and 2 (4a-d).

From this elevated position YHWH observes (עיניו יחזיות, 4c) and examines humankind in general (עפעפיו יבחנו בני אדם (2d) and the righteous in particular (יהוה צדיק יבחן, 5a). He annihilates the wicked (5bc; 6ab) but enables the upright to see his face (ישריחזו פנימו, 7b), a metaphor for experiencing his presence. The notion of YHWH's protective presence $(1 \mathrm{~b} ; 7 \mathrm{~b})$ constitutes an inclusio that is directly linked to his presence in the centre of the poem (and the universe!) in $4 \mathrm{ab}$ and acts as important link between all three stanzas.

The repetition of first as an action of YHWH looking down from his royal throne upon the doings of mankind (4c), then as an action of the upright looking up into YHWH's face (7b) links Stanzas 2 (4a-d) and 3 (5a-7b), as does the repetition of בחן, first as a general act of examining mankind (4d), then as a specific act of examining the righteous (5a). The chiastic arrangement of the

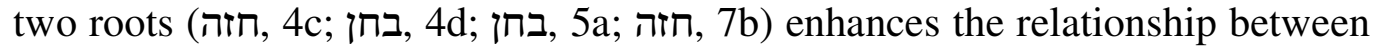
Stanzas 2 (4a-d) and 3 (5a-7b).

Preceding and following the central Stanza 2 (4a-d) important, contrastive repetitions link Stanzas 1 (1b-3b) and 3 (5a-7b). Stanza 1 (1b-3b) commences with the poet's confession of trust in YHWH's protection (1b) followed

same verb, $h z h$ (sic). Face-to-faceness is a gift to the righteous (withheld from the wicked) that makes them safe in a world of threat." 
by the question איך תאמרו לנפשי "how can you tell me?" (1c). נפש suggests the total involvement of the poet (his innermost being) in his refusal to flee (1d). נפש appears again in the opening verse of Stanza 3 (5a-7b) in the expression "his innermost being hates" (5c) to express YHWH's abhorrence of wicked people's love for violence. The wicked have a deeply emotional influence upon the poet and YHWH!

Noticeable is the presence of two opposing groups in both stanzas. In Stanza 1 (1b-3b) the wicked (הרשעים, 2a) are likened to hunters preparing their bows and arrows (2ab), waiting in the darkness to shoot at the upright in heart (ישרי-לב, 4c). This prompts the despairing question in 3b (צדיק מה־פעל"a righteous person - what can he accomplish?"). The righteous appear in this last colon of Stanza 1 (3b) and again in the first colon of Stanza 3 (5a) where they are the object of YHWH's examination (יהוה צדיק יבחן, 5a), thus creating an inclusio between Stanzas 1 (1b-3b) and 3 (5a-7b). The inclusio is enhanced by the reappearance of the wicked in 5b, described as the "wicked" (רשע) and "one who loves violence" (אהב חמס). The terms call the description of the wicked in 2abc to mind. The chiastic repetition צרשעים (2a); צדיק (3b); (5a); רשע (5b) enhances the contrast between the apparent power of the wicked over the righteous in Stanza 1 (1b-3b) and YHWH's protection of the righteous and annihilation of the wicked in Stanza 3 (5a-7b).

In 6ab the wicked (רשעים) become the object of YHWH's judgment. 7a emphasizes that YHWH judges them precisely because he is righteous and loves righteous deeds (כי־צדיק יהוה צדקות אהב (5a). Tדיק (5a); רשדים) The chiastic repetition (5b); צשעים (6a); צדיק/צדקות (7a) enhances the message that YHWH aids the righteous but annihilates the wicked. Two verbs with opposite meanings create an interesting $a-b-a$ pattern in Stanza 3 (5a-7b) and emphasise YHWH's contrastive emotions towards the wicked and the righteous. In $5 \mathrm{~b}$ the wicked is defined as someone who loves violence (ורשע ואהב חמס). Ominously, 5c indicates that YHWH passionately abhors (שנאה נפשו) such people and annihilates perpetrators of such deeds (6ab). In sharp contrast to his hate for violence is his love for righteous deeds, exactly because he is righteous (כי־צדיק יהוה צדקות אהב, 7a). He rewards people doing such deeds with his presence (7b). ${ }^{83}$

A last link between Stanzas 1 (1b-3b) and 3 (5a-7b) is the appearance of the "upright" towards the end of both sections. In $2 c$ the upright in heart (ישרי-לב) are the object of the wicked people's attack. The upright hovers on the brink of death. In $7 \mathrm{~b}$ the upright (ישר) are the people who are granted the privilege of appearing in YHWH's presence and experience his protection.

The data is summarised in the following table:

83 Bellinger, "Interpretation," 99 emphasises the antithetic parallelism in 5b-7b (5b: God hates - 6: God destroys // 7a: God loves - 7b: God rewards). 
798 Prinsloo, “Suffering as Separation,” OTE 28/3 (2015): 777-806

\begin{tabular}{|c|c|c|c|c|c|c|c|c|c|c|c|c|}
\hline Ss & $1 a$ & \multicolumn{11}{|c|}{ Superscript } \\
\hline \multirow{11}{*}{1} & $1 b-3 b$ & \multicolumn{9}{|c|}{ Refuge with YHWH in spite of the attack by the wicked } & \multicolumn{2}{|c|}{ Positive/negative space } \\
\hline & \multirow[t]{4}{*}{$A$} & \multicolumn{9}{|c|}{ I find refuge with $\mathrm{YнWH}$} & צ צ' for ציק & צדיק for \\
\hline & & $1 \mathrm{~b}$ & 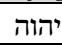 & & & & & & & & 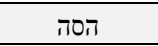 & -- \\
\hline & & $\mathrm{c}$ & & נפש & & & & & & & -- & מה תאמרו \\
\hline & & $\mathrm{d}$ & & & & & & & & & -- & נודי הרכם \\
\hline & \multirow[t]{6}{*}{ 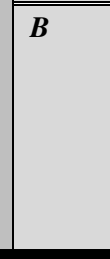 } & \multicolumn{9}{|c|}{ The righteous under attack by the wicked } & צ צ' for ציק & צדיק for \\
\hline & & $2 \mathrm{a}$ & & & רשע & & & & & & -- & ידרכון קשת \\
\hline & & $\mathrm{b}$ & & & & & & & & & -- & כוננו חצם \\
\hline & & $\mathrm{c}$ & & & & ישר & & & & & -- & 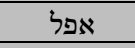 \\
\hline & & $3 \mathrm{a}$ & & & & & & & & & -- & 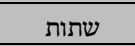 \\
\hline & & $\mathrm{b}$ & & & & & צדיק & & & & -- & 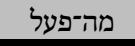 \\
\hline \multirow{6}{*}{2} & $4 a-d$ & \multicolumn{9}{|c|}{ YнWн observes humanity as heavenly king } & \multicolumn{2}{|c|}{ Positive/negative space } \\
\hline & $A$ & \multicolumn{9}{|c|}{ From his temple and heavenly throne Үнwн observes humanity } & + for צדיק & צדיק for \\
\hline & & $4 \mathrm{a}$ & 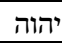 & & & & & & & & היכל & -- \\
\hline & & $\mathrm{b}$ & יהוה & & & & & & & & שמים & -- \\
\hline & & $4 \mathrm{c}$ & & & & & & חזה & & & עיניו יחזו & -- \\
\hline & & $\mathrm{d}$ & & & & & & & 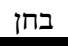 & & 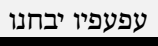 & -- \\
\hline \multirow{10}{*}{3} & $5 a-7 b$ & \multicolumn{9}{|c|}{ YнWн differentiates between the righteous and the wicked } & \multicolumn{2}{|c|}{ Positive/negative space } \\
\hline & $A$ & \multicolumn{9}{|c|}{ "Yнwн examines the righteous but abhors the wicked } & צ' for ציק & רשע for - רשע \\
\hline & & $5 \mathrm{a}$ & 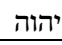 & & & & צדיק & & 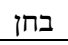 & & צדיק יבחן & -- \\
\hline & & $\mathrm{b}$ & & & רשע & & & & & אהב & -- & ורשע ואהב \\
\hline & & $\mathrm{c}$ & & נפש & & & & & & שנא & -- & שנאה נפשו \\
\hline & $B$ & \multicolumn{9}{|c|}{ YнWн annihilates the wicked but loves the righteous } & צ for ציק & רשע for - רש \\
\hline & & $6 a$ & & & רשע & & & & & & -- & מטר \\
\hline & & $\mathrm{b}$ & & & & & & & & & -- & $\boldsymbol{N}^{\mathrm{etc}}$ \\
\hline & & $7 \mathrm{a}$ & 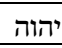 & & & & צדיק & & & 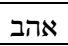 & -- & -- \\
\hline & & $\mathrm{b}$ & & & & ישר & & 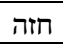 & & & פנים & -- \\
\hline
\end{tabular}

\section{READING PSALM 11 IN ITS "SPACE"}

The analysis of Ps 11 above can now briefly be contextualised in Book I of the Psalter. ${ }^{84}$ There are indications that Pss 11 and 12 can be read as a pair. Psalm 12 comments on the wicked's foolish advice (cf. איך תאמרו לנפשי 11:1) to the suppliant to "flee your mountain little bird!" (נודי הרכם צפור in 11:1). The trustworthiness of YHWH's words (12:6-7) stands in sharp contrast to false and flattering human speech (12:3-5), therefore the poet can claim that YHWH will protect "us" from "this generation" forever (12:8), linking up with the confes-

84 It is not possible to engage in a detailed contextualisation of Ps 11. For a discussion of the psalm group, cf. Hossfeld and Zenger, Psalmen 1, 12-14; Gianni Barbiero, Das erste Psalmenbuch als Einheit: Eine synchrone Analyse von Psalm 1-41 (ÖBS 16; Frankfurt: Peter Lang, 1999), 63-188; Friedhelm Hartenstein, "'Schaffe mir Recht, JHWH!' (Psalm 7,9): Zum theologischen und antropologischen Profil der Teilkomposition Psalm 3-14," in The Composition of the Book of Psalms (ed. Erich Zenger; BETL 238; Leuven: Peeters, 2010), 229-58. I am currently engaged in a detailed spatial analysis of Pss 3-14. What follows is a very brief summary of that still to be published research. 
sion of trust in 11:1 (ביהוה חסיתי). The remark in 11:4 that YHWH's "eyelids examine the sons of humankind" (עפעפיו יבחנו בני אדם) has ominous implications for the בני אדם "the sons of humankind" which occurs in the first (cf. 12:2) and last (cf. 12:9) verse of Ps 12. The "faithful" might have "vanished from among the sons of humankind" (12:2; cf. 11:3) and "vileness" might be "raised high among the sons of humankind" (12:9), but YHWH "at centre" (11:4) declares in the centrally located 12:6: "Because of the oppression of the poor, the groaning of the needy, I will now stand up,' YHWH says, 'I will set him in the salvation that he longs for." "85

A cursory reading of Pss 3-14 makes it clear that, with the exception of Ps 8 , every poem contains references to a direct confrontation between a righteous sufferer and enemies. ${ }^{86}$ In all but Pss 10 and 14 the poet as a 1 st person singular speaker acts on behalf of the righteous. The enmity has the effect of alienation, therefore the poet experiences YHWH as far away and himself and his group as "off-centre." ${ }^{87}$ With the exception of Pss 8 and 11, every poem in the collection contains an urgent prayer for salvation. ${ }^{88}$ The prayer constitutes a plea to YHWH to draw near in order that the righteous might experience his presence and be "at-centre." The righteous' experience of being "off-centre" can be plotted on both the horizontal and vertical axes. Horizontally, the confrontation with enemies brings about estrangement from YHWH. Vertically, the confrontation leads to an existence on the brink of disaster and death. The poet experiences this as being in the clutches of שאול itself.

In this context Ps 8 plays a crucial role. This song of praise refers on all three levels of the universe and its orientation is decidedly vertical. YHWH reigns upon earth $(8: 1,10)$, but his majesty also becomes apparent in heaven $(8: 1,4,9)$ and in the sea $(8: 9)$. YHWH engages with all of creation and especially with all of humankind (8:4), significantly called בני־אדם and Y Y Y Y this insignificant being (8:5) is little less than God and crowned with glory and honour (8:6). Humankind is YHWH's "vassal" who rule over creation on his behalf (8:7-9). Yet there is a precondition (8:3). It can only happen where humankind recognises YHWH's glory and kingship, become "children and infants" by relying upon him completely. Then he silences the raging of "foe and avenger." In contrast with the preceding Pss 3-7 and the following Pss 9-14 mankind is here depicted as potentially completely "at-centre," but it can only

85 Gert T. M. Prinsloo, "Man's Word - God's Word: A Theology of Antithesis in Psalm 12," ZAW 110 (1998): 390-402 (400-401).

86 Psalms 3:2, 3, 7, 8; 4:3, 7; 5:5-7, 9-11; 6:9, 11; 7:2-3, 6, 15-17; 9:6-7, 14-15, 20$21 ; 10: 2-11 ; 11: 2-3 ; 12: 3,9 ; 13: 5 ; 14: 1-3,6$.

87 The notion is present in all the poems, but finds it most pertinent expression in 10:1.

88 Psalms $3: 8 ; 4: 1 ; 5: 2-3,9,11-12 ; 6: 2-6 ; 7: 2,7-10 ; 9: 14-15,20-21 ; 10: 12-13,15$; $12: 2,4-5 ; 13: 4-5 ; 14: 7$. 
happen when YHWH is recognised as the ultimate ruler. This notion puts the apparent power of the wicked in 3-7 and 9-14 in perspective.

From this centre, Pss 3-7 can be read as the desperate attempt of the righteous sufferer to draw close to YHWH. Three times the temple is explicitly mentioned as the space where one can experience YHWH and his presence (3:5; $4: 6 ; 5: 8)$. Yet the righteous sufferer is thwarted in his attempts by the ferocious attack of the wicked. In spite of his trust in YHWH all seems to be in vain and he arrives at the gates of death (6:6). The sufferer's only hope lies in taking refuge in YHWH (7:2) and in his urgent prayer that YHWH "most high" (7:9, 11, 18) might rule over the wicked nations "from on high" (7:8)! Only when the sufferer orientates himself vertically towards YHWH the heavenly king is he able to broach the distance and move towards the centre. This process reaches its culmination point in Ps 8 .

Psalm 9 commences where Ps 8 concludes - with the psalmist in the presence of YHWH Most High (9:3). The call to praise at the end of Ps 7 (7:18) is repeated in Ps 9:1 (and illustrated in Ps 8!) and directly links Pss 3-7 to 9-14. There are two subtle differences between the two groups of poems, though. First, the individual perspective of Pss 3-7 makes room for a collective view. The poet becomes a spokesperson for a social group calling themselves the "poor." They are present in Pss 9, 10, 12 and 14 and are explicitly identified in 14:7 as Israel and Jacob. ${ }^{89}$ Second, the wicked become the protagonists in Pss 9-14 who are doing their utmost to destroy the "poor" and who deny the kingship of YHWH. ${ }^{90}$ In the light of Ps 8 these people can only be brought to task if the "poor" react like "children and infants" (8:3) by singing YHWH's praise and doing righteous deeds (11:7). Therefore a "heavenly" perspective, a vertical orientation, permeates Pss 9-14, starting with 9:1-13 and culminating in the prayer for the salvation of Israel from Zion in 14:7. The harder the wicked try to drive the "poor" off-centre, the more they focus upon YHWH on his heavenly throne $(9: 5,8 ; 11: 4)$ ! The off-centre suppliant of Pss 3-7 becomes the at-centre poor of Pss 9-14, because "YHWH is in his holy temple, in the heavens is his throne" (11:4). ${ }^{91}$ In this way Pss 3-14, and especially 9-14, prepare the way for Pss 15-24's focus upon the temple (Ps 15, 24), heaven and Torah (Ps 19).

89 Psalms 9:10, 13, 19; 10:9, 12, 14, 17-18; 12:6; 14:6.

90 Psalms 10:3-4, 11, 13; 12:4-5; 14:1.

91 Ulrich Berges, “'God Staat aan de Kant van de Armen' (Ps. 109, 31): Armoede en Rijkdom in het Psalmenboek," TvT 44 (2004): 108-123 (111) remarks: "De klachten en gebeden van Ps. 3-7 schilderen situasies waarin degene die bidt onder druk staat van persoonlike vijanden, van het gemis aan rechtzekerheid en van ziekte, en hoopt op de morgen als tijd van Gods hulp (3, 6; 5, 4). Daarna gaan Ps. 9-14 boven de persoonlijke levenssituasie uit en spreken van structurele bedreigingen waar de gemeenschap van JHWH-getrouwen tegen moet strijden. Interessant genoeg kreeg midden tussen deze klaag- en smeekgebeden Ps. 8 een plaats." 
The superscript (1a) implies that Ps 11 should be read in the light of the real-life experiences of the poet as the "imaginary" David who is depicted in Book I of the Psalter as the suffering and lamenting David, threatened by enemies, fleeing before Saul (Ps 3:1), the object of scorn (Ps 7:1; Ps 34:1), but also saved by YHWH (Ps 18:1). Psalm 11 shares with other poems in Book I the notion of Zion/Jerusalem/temple/mountain as the cosmic centre of the universe, the only place where a righteous person can be at-centre. ${ }^{92}$

The social group responsible for the so-called "poor" redaction of the Psalter is at work in Pss 3-14 and is probably responsible for the final shape of the psalm group. They are the "servants" of YHWH who often refer to themselves as the "poor," the "upright," or the "righteous." They have been identified as groups of Levites who lived and worked towards the end of the Persian Period in the province of Yehud and experienced themselves as being isolated from the centre of power in Jerusalem. They lament their desperate situation, plea with YHWH for deliverance, identify themselves as the "true" Israel who, under the kingship of YHWH and his anointed will truly serve YHWH in his temple and live life at-centre in the presence of $\mathrm{YHWH}^{93}$

\section{E CONCLUSION}

Psalm 11 is not a colourless and forgettable composition. A spatial reading of the poem reveals its vertical orientation towards YHWH in his temple and upon his heavenly throne (11:4). It puts the apparent power of the wicked in perspective (11:1-3) and ensures the destruction of the wicked and a life in the presence of YHWH (11:5-7). The experience of being under constant threat (11:2) causes an existential crisis to the poet. The experience of the very foundations of society, indeed of the cosmos itself being destroyed (11:3) leads to the despairing question "what can a righteous person accomplish?" (11:3). It can be construed as a "struggle to construct meaning."94 The righteous stands on the brink of the abyss, decidedly off-centre, far from YHWH and his saving presence. The poet experiences suffering as separation. In the universe as imagined by the poet there is but one solution: to take refuge in YHWH (11:1)

92 Pss 3; 5; 7, 9, 11, 14, 15, 18, 20, 21, 23, 24, 26, 27, 28, 29 (cf. Gillingham, "Zion Tradition," 316).

93 Much work has been done on the role of this post-exilic group and their literary heritage, cf. especially Ulrich Berges, "Die Armen im Buch Jesaja: Ein Beitrag zur Literaturgeschichte des AT," Bib 80 (1999): 153-77; Ulrich Berges, "Die Knechte im Psalter: Ein Beitrag zu seiner Kompositionsgeschichte," Bib 81 (2000): 153-78; Ulrich Berges, "Who Were the Servants? A Comparative Inquiry in the Book of Isaiah and the Psalms," in Past, Present, Future: The Deuteronomistic History and the Prophets (ed. Johannes C. de Moor and Herrie F. van Rooy; OtSt 44; Leiden: Brill, 2000), 1-18; Johannes Un-Sok Ro, Die sogenannte „Armenfrömmigkeit“ im nachexilischen Israel (BZAW 322; Berlin: De Gruyter, 2002).

94 Boase, "Constructing Meaning," 449. 
at-centre. That confession, amidst the crumbling of personal security and comfort (11:2-3), draws the eyes of the poet to YHWH in his holy temple and at the same time enthroned as king of the universe. In 11:4 the poet's imagined space literally transports him from שמים to שאול There, in the presence of YHWH (11:7), he arrives at-centre once again, convinced that the wicked will finally be destroyed. In the poet's imagined universe suffering is obliterated in the presence of YHWH.

\section{BIBLIOGRAPHY}

Auffret, Pierre. "Essai sur la structure littéraire du psaume 11." Zeitschrift für die Alttestamentliche Wissenschaft 93 (1981): 401-18.

Baethgen, Friedrich. Die Psalmen. Handkommentar zum Alten Testament II/2. Göttingen: Vandenhoeck and Ruprecht, 1904.

Barbiero, Gianni. Das erste Psalmenbuch als Einheit: Eine synchrone Analyse von Psalm 1-41. Österreichsche Biblische Studien 16. Frankfurt: Peter Lang, 1999.

Bellinger, William H. “The Interpretation of Psalm 11.” Evangelical Quarterly 56 (1984): 95-101.

Berges, Ulrich. "Die Armen im Buch Jesaja: Ein Beitrag zur Literaturgeschichte des AT." Biblica 80 (1999): 153-77. . "Die Knechte im Psalter: Ein Beitrag zu seiner Kompositionsgeschichte." Biblica 81 (2000): 153-78.

. "Who Were the Servants? A Comparative Inquiry in the Book of Isaiah and the Psalms." Pages 1-18 in Past, Present, Future: The Deuteronomistic History and the Prophets. Edited by Johannes C. de Moor and Herrie F. van Rooy. Oudtestamentische Studien 44. Leiden: Brill, 2000.

. “God Staat aan de Kant van de Armen' (Ps. 109, 31): Armoede en Rijkdom in het Psalmenboek." Tijdschrift voor Theologie 44 (2004): 108-123.

Berlejung, Angelika. "Weltbild/Kosmologie." Pages 65-72 in Handbuch theologischer Grundbegriffe zum alten und neuen Testament. Edited by Angelika Berlejung and Christian Frevel. Darmstadt: Wissenschaftliche Buchgesellschaft. 2006.

Berquist, Jon L. "Critical Spatiality and the Construction of the Ancient World." Pages 14-29 in 'Imagining' Biblical Worlds: Studies in Spatial, Social and Historical Constructs in Honor of James W. Flanagan. Edited by David M. Gunn and Paula M. McNutt. Journal for the Study of the Old Testament Supplement Series 359. Sheffield: Sheffield Academic Press, 2002.

Bewer, Julius A. "Text-Critical Suggestions on Hosea xii. 1, iv. 4, iv.8; Isaiah xiv. 12 ; Psalm xi. 1." Journal of Biblical Literature 21 (1902): 108-114.

Beyerlin, Walter. Die Rettung der Bedrängten in den Feindpsalmen der Einzelnen auf institutionelle Zusammenhänge untersucht. Forschungen zur Religion und Literatur des Alten und Neuen Testaments 99. Göttingen: Vandenhoeck and Ruprecht, 1970.

Birkeland, Harris. Die Feinde des Individuums in der israelitischen Psalmenliteratur: Ein Beitrag zur Kenntnis der semitischen Literatur- und Religionsgeschichte. Oslo: Grøndahl, 1933.

Boase, Elizabeth. "Constructing Meaning in the Face of Suffering: Theodicy in Lamentations.” Vetus Testamentum 58 (2008): 449-68. 
Bratcher, Robert C. and William D. Reyburn. A Translator's Handbook on the Book of Psalms. Helps for Translators. New York: United Bible Societies, 1991.

Brettler, Marc. Z. God is King: Understanding an Israelite Metaphor. Journal for the Study of the Old Testament Supplement Series 76. Sheffield: JSOT Press, 1989.

Briggs, Charles A. and Emilie G. Briggs. A Critical and Exegetical Commentary on the Book of Psalms. Volume 1. International Critical Commentary. Edinburgh: T\&T Clark, 1906.

Broyles, Craig C. The Conflict of Faith and Experience in the Psalms: A Formcritical and Theological Study. Sheffield: JSOT Press, 1989.

Brueggemann, Walter. "Theodicy in a Social Dimension." Journal for the Study of the Old Testament 33 (1983): 3-25.

. "Some Aspects of Theodicy in Old Testament Faith." Perspectives in Religious Studies 26 (1999): 253-68.

Brueggemann, Walter and William H. Bellinger. Psalms. New Cambridge Bible Commentary. Cambridge: Cambridge University Press, 2014.

Buttenwieser, Moses. The Psalms. Chicago: University of Chicago Press, 1938.

Campbell, Tony. "God and Suffering - 'It Happens': Job's Silent Solution." American Theological Inquiry 3 (2010): 153-63.

Craigie, Peter. Psalms 1-50. Word Biblical Commentary 19. Nashville, Tenn.:Thomas Nelson, 2004.

Creach, Jerome F. D. Yahweh as Refuge and the Editing of the Hebrew Psalter. Journal for the Study of the Old Testament Supplement Series 217. Sheffield: Sheffield Academic Press, 1996.

Crenshaw, James L., ed. Theodicy in the Old Testament. Issues in Religion and Theology 4. Philadelphia: Fortress, 1983.

Flynn, Shawn W. YHWH is King: The Development of Divine Kingship in Ancient Israel. Supplements to Vetus Testamentum 159. Leiden: Brill, 2014.

Gerleman, Gilles. "Der 'Einzelne' der Klage- und Dankpsalmen." Vetus Testamentum 32 (1982): 33-49.

Gerstenberger, Erhard S. and Wolfgang Schrage, eds. Leiden. Biblische Konfrontationen 1004. Köln: Kohlhammer, 1977.

Gerstenberger, Erhard S. Psalms Part I with an Introduction to Cultic Poetry. Forms of Old Testament Literature 14. Grand Rapids, Mich.: Eerdmans, 1988.

Gesenius, Wilhelm, Emil Kautzsch and Arthur E. Cowley. Gesenius' Hebrew Grammar. 2nd English ed. Oxford: Clarendon Press, 1910

Gillingham, Susan. "The Zion Tradition and the Editing of the Hebrew Psalter." Pages 308-41 in Temple and Worship in Biblical Israel: Proceedings of the Oxford Seminar. Edited by John Day. London: T\&T Clark, 2007.

. "The Levitical Singers and the Editing of the Hebrew Psalter." Pages 91123 in The Composition of the Book of Psalms. Edited by Erich Zenger. Bibliotheca ephemeridum theologicarum lovaniensium 238. Leuven: Peeters, 2010.

Gunkel, Hermann. Die Psalmen. Göttinger Handkommentar zum Alten Testament II/2. Göttingen: Vandenhoeck and Ruprecht, 1929.

Gunkel, Hermann and Joachim Begrich. Einleitung in die Psalmen: Die Gattungen der religiösen Lyrik Israels. Göttinger Handkommentar zum Alten Testament II. Göttingen: Vandenhoeck and Ruprecht, 1933. 
804 Prinsloo, "Suffering as Separation," OTE 28/3 (2015): 777-806

Hartenstein, Friedhelm. "'Schaffe mir Recht, JHwH!' (Psalm 7,9): Zum theologischen und antropologischen Profil der Teilkomposition Psalm 3-14." Pages 229-58 in The Composition of the Book of Psalms. Edited by Erich Zenger. Bibliotheca Ephemeridum Theologicarum Lovaniensium 238. Leuven: Peeters, 2010.

Horowitz, Wayne. Mesopotamian Cosmic Geography. Mesopotamian Civilizations 8. Winona Lake, Ind.: Eisenbrauns, 1998.

Hossfeld, Frank-Lothar and Erich Zenger. Psalm 1-50. Volume 1 of Die Psalmen. Neue Echter Bibel 29. Würzburg: Echter Verlag, 1993.

Janowski, Bernd. "Das biblische Weltbild: Eine methodologische skizze." Pages 3-26 in Das biblische Weltbild und seine altorientalischen Kontext. Edited by Bernd Janowski and Beate Ego. Tübingen: Mohr Siebeck, 2001.

."Die heilige Wohnung des Höchsten: Kosmologische Implikationen der Jerusalemer Tempeltheologie." Pages 24-68 in Gottesstadt und Gottesgarten: $\mathrm{Zu}$ Geschichte und Theologie des Jerusalemer Tempels. Edited by Othmar Keel and Erich Zenger. Quaestiones Disputatae 91. Freiburg: Herder, 2002.

."Ein Tempel aus Worten: Zut theologischen Architektur des Psalters." Pages 279-306 in The Composition of the Book of Psalms. Edited by Erich Zenger. Bibliotheca ephemeridum theologicarum lovaniensium 238. Leuven: Peeters, 2010.

Johnston, Philip S. "Ordeals in the Psalms?" Pages 271-91 in Temple and Worship in Biblical Israel: Proceedings of the Oxford Seminar. Edited by John Day. London: T\&T Clark, 2007.

Kessler, Hans. Gott und das Leid seiner Schöpfung: Nachdenkliches zur Theodizeefrage. Würzburg: Echter Verlag, 2000.

Koehler, Ludwig, Walter Baumgartner and Johann J. Stamm. The Hebrew and Aramaic Lexicon of the Old Testament. Translated and edited under the supervision of M. E. J. Richardson. 4 vols. Leiden, 1994-1999

Kraus, Hans-Joachim. Psalms 1-59. Translated by Hilton C. Oswald. Minneapolis: Augsburg, 1988.

Krüger, Annette. "Himmel - Erde - Unterwelt. Kosmologische Entwürfe in der poetischen Literatur Israels." Pages 65-83 in Das biblische Weltbild und seine altorientalischen Kontext. Edited by Bernd Janowski and Beate Ego. Tübingen: Mohr Siebeck, 2001.

Laatto, Antii and Johannes C. de Moor, eds. Theodicy in the World of the Bible. Leiden: Brill, 2003.

Lefebvre, Henri. The Production of Space. Translated by D. Nicholson-Smith. Oxford: Blackwell, 1991.

Leibniz, Gottfried W. Theodicy: Essays on the Goodness of God, the Freedom of Man and the Origin of Evil. Translated by E. M. Huggard. New York: Cosimo, 2009.

Lindström, Fredrik. Suffering and Sin. Translated by M. McLamb. Stockholm: Almqvist \& Wiksell, 1994.

Loretz, Oswald. Psalmstudien: Kolometrie, Strophik und Theologie ausgewählter Psalmen. Beihefte zur Zeitschrift für die Alttestamentliche Wissenschaft 309. Berlin: Walter de Gruyter, 2002.

Mays, James L. Psalms. Interpretation Bible Commentary. Louisville, Ky.: John Knox, 1994. 
Melvin, David P. "Why Does the Way of the Wicked Prosper? Human and Divine Suffering in Jeremiah 11:18-12:13 and the Problem of Evil." Evangelical Quarterly 83 (2011): 99-106.

Mettinger, Tryggve N. D. In Search of God: The Meaning and Message of the Everlasting Names. Translated by F. H. Cryer. Philadelphia: Fortress, 1978.

Moore, Ralph K. An Investigation of the Motif of Suffering in the Psalms of Lamentation. Ann Arbor, Mich.: University Microfilms International, 1993.

Morgenstern, Julian. "Psalm 11." Journal of Biblical Literature 69 (1950): 221-31.

Ngwa, Kenneth. "Did Job Suffer for Nothing? The Ethics of Piety, Presumption and the Reception of Disaster in the Prologue of Job." Journal for the Study of the Old Testament 33 (2009): 359-80.

Nogalski, James D. "Recurring Themes in the Book of the Twelve: Creating Points of Contact for a Theological Reading." Interpretation 61 (2007): 125-36.

Prinsloo, Gert T. M. “Man's Word - God's Word: A Theology of Antithesis in Psalm 12." Zeitschrift fur die Alttestamentliche Wissenschaft 110 (1998): 390-402. ."The Role of Space in the שירי המעלות (Psalms 120-134)." Biblica 86 (2005): 457-77. . "Še ôl $\rightarrow$ Yerûšālayim $\leftarrow$ Šāmayim: Spatial Orientation in the Egyptian Hallel (Psalms 113-118)." Old Testament Essays 19 (2006): 739-60. ."Place, Space and Identity in the Ancient Mediterranean World: Theory and Practice with Reference to the Book of Jonah." Pages 3-25 in Place, Space and Identity in the Ancient Mediterranean World. Volume 5 of Constructions of Space. Edited by Gert T. M. Prinsloo and Christl M. Maier. Library of Hebrew Bible/Old Testament Studies 576. New York: Bloomsbury T\&T Clark, 2013. "Suffering Bodies - Divine Absence: Towards a Spatial Reading of Ancient Near Eastern Laments with Reference to Psalm 13 and An Assyrian Elegy (K 890)." Old Testament Essays 26 (2013): 773-803.

Raabe, Paul R. 'Deliberate Ambiguity in the Psalter.' Journal of Biblical Literature 110 (1991): 213-27.

Riede, Peter. Im Netz des Jägers: Studien zur Feindmetaphorik der Individualpsalmen. Wissenschaftliche Monographien zum Alten und Neuen Testament 85. Neukirchen-Vluyn: Neukirchener Verlag, 2000.

Ro, Johannes Un-Sok. Die sogenannte „Armenfrömmigkeit“ im nachexilischen Israel. Beihefte zur Zeitschrift für die alttestamentliche Wissenschaft 322. Berlin: De Gruyter, 2002.

Schmidt, Hans. Die Psalmen. Handbuch zum Alten Testament 15. Tübingen: Mohr, 1934.

Schönemann, Hubertus. Der untreue Gott und sein treues Volk: Anklage Gottes angesichts unschuldigen Leidens nach Psalm 44. Bonner Biblische Beiträge 157. Göttingen: Vandenhoeck \& Ruprecht, 2009.

Seybold, Klaus. Die Psalmen. Handbuch zum Alten Testament I/15. Tübingen: Mohr, 1996.

Sonne, Isaiah. "Psalm 11.” Journal of Biblical Literature 68 (1949): 241-5.

Soja, Edward W. Thirdspace: Journeys to Los Angeles and Other Real-and-Imagined Places. Oxford: Blackwell, 1996.

TeSelle, Sallie M. Speaking in Parables: A Study in Metaphor and Theology. Philadelphia: Fortress, 1975. 
806 Prinsloo, “Suffering as Separation," OTE 28/3 (2015): 777-806

Thompson, Leonard L. Introducing Biblical Literature: A More Fantastic Country. Engelwood Cliffs, N.J.: Prentice-Hall, 1978.

Tuan, Yi-Fu. Space and Place: The Perspective of Experience. Minneapolis: University of Minnesota Press, 2008.

Van der Toorn, Karel. "Ordeal Procedures in the Psalms and the Passover Meal." Vetus Testamentum 38 (1988): 427-45.

Van Uchelen, Nico A. 1-40. Volume 1 of Psalmen. De Prediking van het Oude Testament. Nijkerk: Callenbach, 1979.

VanGemeren, Willem A. Psalms. Expositor's Bible Commentary 5. Grand Rapids, Mich.: Zondervan, 1991.

Warrington, Keith. "Healing and Suffering in the Bible." International Review of Mission 93 (2006): 154-64.

Waters, Larry J. "Elihu's Categories of Suffering from Job 32-37." Bibliotheca Sacra 166 (2009): 405-20.

Watts, John D. W. "Psalms of Trust, Thanksgiving, and Praise." Review and Expositor 81 (1984): 395-406.

Weiser, Arthur. The Psalms. Translated by H. Hartwell. Old Testament Library. London: SCM, 1962.

Westermann, Claus. Praise and Lament in the Psalms. Translated by Richard N. Soulen and Keith R Crim. Atlanta: John Knox, 1981.

Willis, John T. "The Dignity and Suffering of Humankind According to the Hebrew Bible.” Stone-Campbell Journal 1 (1998): 231-241

Wilson, Gerald H. The Editing of the Hebrew Psalter. Society of Biblical Literature Dissertation Series 76. Chico, Calif.: Scholars, 1981.

Wyatt, Nicolas. Space and Time in the Religious Life of the Near East. Sheffield: Sheffield Academic Press, 2001.

Zenger, Erich. "Der Psalter als Wegweiser und Wegbegleiter: Ps 1-2 als Proömium des Psalmenbuchs." Pages 29-47 in Sie wandern von Kraft zu Kraft: Aufbrüche, Wege, Begegnungen: Festgabe für Bischof Reinhard Lettmann. Edited by Arnold Angenendt and Herbert Vorgrimler. Kevelaer: Butzon \& Bercker, 1993.

Gert T. M. Prinsloo, Department of Ancient Languages and Cultures, University of Pretoria, Pretoria, 0002, South Africa. Email: gert.prinsloo @up.ac.za. 